Expenses of the Lunacy Commission.--The expenses of the Lunacy Commission for the year ending July, 1856, were $£ 13,158$. This sum does not include the amount expended in prosecutions.

Dr. Robertson has to communicate the following letter :

Office of Commissioners in Lunacy, 19, Whitehall Place,

Dear Sir, January 20, 1857.

In looking over my papers, I find a letter from you announcing that the Association of Medical Officers of Asylums and Hospitals for the Insane, had done me the honour of electing me an honorary member. I much fear that a pressure of engagements during the last few months may have caused me to neglect acknowledging this, and expressing my thanks; and if so, I beg that you will accept every apology for the omission.

I am, dear Sir, faithfully yours,

L. Robertson, Esq., M.D., \&c., \&c.

\title{
JAMES WILKES.
}

Dr. Hume, Commissioner in Lunacy, died on the 1st ult., deeply regretted, in the 79th year of his age. He was an Army Surgeon, and private medical attendant to the late Duke of Wellington.

Dr. NaIrne, late Physician to St. George's Hospital, has been appointed to succeed Dr. Hume at the councils of the Lunacy Board. 